Dalton Transactions, 2005, (5), 896 - 902

DOI: $10.1039 / \mathrm{b} 416711 \mathrm{~b}$

\title{
Metal-assisted red light-induced DNA cleavage by ternary L-methionine copper(II) complexes of planar heterocyclic bases $\_$
}

Paper

\author{
Ashis K. Patra, Shanta Dhar, Munirathinam Nethaji and Akhil R. Chakravarty* \\ Department of Inorganic and Physical Chemistry, Indian Institute of Science, Bangalore 560 012, India. \\ E-mail: arc@ipc.iisc.ernet.in; Fax: +91802360683
}

Received 1st November 2004, Accepted 12th January 2005

First published on the web 24th January 2005

Ternary copper(II) complexes $[\mathrm{Cu}(\mathrm{L}-\mathrm{met}) \mathrm{B}(\mathrm{Solv})]\left(\mathrm{ClO}_{4}\right)(\mathbf{1 - 4})$, where $\mathrm{B}$ is a N,N-donor heterocyclic base like 2,2'-bipyridine (bpy, 1), 1,10-phenanthroline (phen, 2), dipyrido[3,2-d:2',3'-f]quinoxaline $(\mathrm{dpq}, 3)$ and dipyrido[3,2- $\left.a: 2^{\prime}, 3^{\prime}-c\right]$ phenazene $(\mathrm{dppz}, 4)$, are prepared and their DNA binding and photoinduced DNA cleavage activity studied (L-Hmet $=$ L-methionine). Complex 2, structurally characterized by X-ray crystallography, shows a square pyramidal $(4+1)$ coordination geometry in which the N,Odonor L-methionine and N,N-donor heterocyclic base bind at the basal plane and a solvent molecule is coordinated at the axial site. The complexes display a $\mathrm{d}-\mathrm{d}$ band at $\sim 600 \mathrm{~nm}$ in DMF and exhibit a cyclic voltammetric response due to the $\mathrm{Cu}(\mathrm{II}) / \mathrm{Cu}$ (I) couple near $-0.1 \mathrm{~V}$ in DMF-Tris-HCl buffer. The complexes display significant binding propensity to the calf thymus DNA in the order: $\mathbf{4}(\mathrm{dppz})>\mathbf{3}$ $(\mathrm{dpq})>\mathbf{2}$ (phen) $\gg \mathbf{1}$ (bpy). Control cleavage experiments using pUC19 supercoiled DNA and distamycin suggest major groove binding for the dppz and minor groove binding for the other complexes. Complexes $\mathbf{2} \mathbf{- 4}$ show efficient DNA cleavage activity on UV (365 nm) or red light (632.8 $\mathrm{nm}$ ) irradiation via a mechanistic pathway involving formation of singlet oxygen as the reactive species. The DNA cleavage activity of the dpq complex $\mathbf{3}$ is found to be significantly more than its dppz and phen analogues.

\section{Introduction}

Compounds having the ability to bind and cleave double stranded DNA under physiological conditions are of importance for their utility as diagnostic agents in medicinal applications and for genomic research. $\frac{1-10}{}$ The DNA cleavage reactions generally proceed via oxidative or hydrolytic cleavage pathways. The hydrolytic pathway involves phosphodiester bond hydrolysis leading to the formation of fragments that could be religated through enzymatic processes. The oxidative process results in the nucleobase oxidation and/or degradation of sugar by abstraction of sugar hydrogen atom(s). Among different methodologies adopted for oxidative cleavage of DNA, the one based on irradiation with visible light of long wavelength has gained importance for their potential use in photodynamic therapy (PDT) of cancer. $\frac{11-14}{2}$ PDT is a non-invasive treatment of tumor by the combined use of red light and a photosensitizing drug which on photo-excitation transfers its excited state energy to molecular oxygen in 
a type-II process forming singlet oxygen that causes oxidative cellular damage. The porphyrinic species Photofrin ${ }^{\circledR}$ is currently used as an anticancer PDT drug which is active on $630 \mathrm{~nm}$ photo-irradiation. $\frac{15}{}$ We are involved in the development of the chemistry of non-porphyrinic low molecular weight copperbased complexes as new photoactive DNA cleaving agents. $\frac{16-20}{2}$

The present work stems from our interest to design ternary copper(II) complexes containing bioessential $\boldsymbol{\alpha}$-amino acid L-methionine as a photosensitizer and $\mathrm{N}, \mathrm{N}$-donor heterocyclic bases as DNA groove binders. Amino acid and peptide-based transition metal complexes without having any photoactive group are used as synthetic hydrolases and chemical nucleases. $\frac{21-26}{2}$ Amino acids and peptides tethered with photoactive organic molecules are known to cleave DNA on photoirradiation at UV light. $\frac{27,28}{}$ Mahon and coworkers have reported the photosensitized DNA cleavage activity of fluorescent DNA intercalator thiazole orange conjugated to synthetic dipeptides through a quinoline nitrogen linker..$^{27}$ These compounds show DNA cleavage by a type-II process on irradiation at $365 \mathrm{~nm}$ which does not fall in the PDT window of 600-800 nm (red light). A similar synthetic design has been reported by Saito et al. and their L-lysine derivatives possessing a 1,8-naphthalimide chromophore are shown to be photoactive DNA-cleaving agents at UV light of wavelength $320-380 \mathrm{~nm} . \underline{28}$ These organic molecules of the type "A-B" having amino acid moiety (A) covalently linked to the photoactive DNA intercalators (B) are effective only on UV light exposure and are thus not suitable for PDT applications. We have designed new ternary copper(II) complexes of the type "A-Cu$-\mathrm{Cu}^{\mathrm{II}}$ " in which the amino acid (A) and the DNA binder (B) are linked through a copper(II) center with the aim to involve the metal based $d-d$ and/or charge transfer band(s) in the photoexcitation process. In doing so, we have been successful in observing a dramatic shift of the photoactive wavelength to the PDT window on complexation of the $\alpha$-amino acid L-methionine and planar phenanthroline bases to the $\mathrm{d}^{9}$-copper(II) ion.

Our choice of dipyridoquinoxaline and dipyridophenazine ligands as DNA binder/photosensitizer is based on the fact that DNA intercalator quinoxalines which are similar to those present in the antitumor antibiotics echinomycin or tristotin are known to cleave DNA at $365 \mathrm{~nm}$ with the photo-excited ${ }^{3}\left(\mathrm{n}-\pi^{*}\right)$ and/or ${ }^{3}\left(\pi-\pi^{*}\right)$ state(s) causing DNA cleavage in an oxidative manner. ${ }^{29}$ In addition, L-methionine with a thiomethyl group is expected to be a photosensitizer as compounds containing thio- or thione moieties are known to show efficient intersystem crossing leading to the formation of reactive singlet oxygen. $\cdot \frac{30,31}{2}$ The copper ion in the ternary structure is found to play a significant role in effecting the photocleavage of DNA on red light irradiation. Herein we report the synthesis, structure and photo-induced DNA cleavage activity of a series of L-methionine (L-Hmet) copper(II) complexes of formulation [Cu(L-met)B (Solv) $]\left(\mathrm{ClO}_{4}\right)(\mathbf{1 - 4})$, where $\mathrm{B}$ is a N,N-donor heterocyclic base like 2,2'-bipyridine (bpy, 1), 1,10phenanthroline (phen, 2), dipyrido[3,2-d:2, $\left.3^{\prime}-f\right]$ quinoxaline (dpq, 3) and dipyrido[3,2- $\left.a: 2^{\prime}, 3^{\prime}-c\right]$ phenazene (dppz, 4), and Solv is $\mathrm{H}_{2} \mathrm{O}$ for $\mathbf{1 , 3}, \mathbf{4}$ and $\mathrm{MeOH}$ for 2 (Scheme 1). Significant results of this study are the groove binding differences of the complexes and efficient red light induced DNA cleavage activity of the complexes $\mathbf{3}$ and $\mathbf{4}$ at $632.8 \mathrm{~nm}$ which is close to the photoactivation wavelength of Photofrin ${ }^{\circledR}$. A preliminary account of 2 has been reported. $\frac{32}{2}$ 


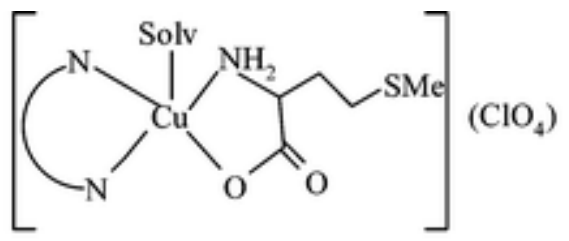<smiles>CCCCCOc1cccc(C(C)(C)C)c1</smiles>

Scheme 1 Complexes 1-4 and the heterocyclic bases.

\section{Results and discussion}

\section{Synthesis and general aspects}

Our major objective in the synthesis of four ternary copper(II) complexes is to explore the role of the metal in the photo-induced DNA cleavage reactions in the presence of an amino acid and a DNA binder. We have chosen L-methionine as the amino acid with a photoactive thiomethyl group. Our choice for planar phenanthroline bases is based on their good binding ability to DNA as well as for their photosensitizing abilities. $\frac{29,33-35}{}$ The ternary complexes are synthesized in good yield by reacting the in situ generated sodium salt of L-methionine with $\mathrm{CuSO}_{4} \cdot 5 \mathrm{H}_{2} \mathrm{O}$ and the heterocyclic base. They are isolated as perchlorate salts of formula $[\mathrm{Cu}(\mathrm{L}-\mathrm{met}) \mathrm{B}(\mathrm{Solv})]\left(\mathrm{ClO}_{4}\right)(\mathbf{1 - 4})$, where $\mathrm{B}$ is the $\mathrm{N}, \mathrm{N}$-donor heterocyclic base (bpy, 1; phen, 2; dpq, 3; and dppz, 4) and Solv is a solvent molecule $\left(\mathrm{H}_{2} \mathrm{O}\right.$ for 1, 3, 4 and $\mathrm{MeOH}$ for 2) (Scheme 1). We have also prepared a known ternary copper(II) complex [Cu(L-phe) (phen) $\left.\left(\mathrm{H}_{2} \mathrm{O}\right)\right]\left(\mathrm{ClO}_{4}\right)^{36}$ for control DNA cleavage experiments to compare the photosensitizing abilities of the amino acids, viz.L-phenylalanine (L-phe) and L-methionine. The complexes are characterized from analytical and physicochemical data (Table 1). The one-electron paramagnetic complexes show a broad $\mathrm{d}-\mathrm{d}$ band near $600 \mathrm{~nm}$ in DMF (Fig. 1). The complexes display a quasireversible cyclic voltammetric response which can be assigned to the $\mathrm{Cu}(\mathrm{II}) / \mathrm{Cu}(\mathrm{I})$ couple near $-0.1 \mathrm{~V}$ in DMF-Tris buffer $(1: 4 \mathrm{v} / \mathrm{v}$; $\mathrm{pH}$ 7.2) (Fig. 1). The high $\Delta E_{\mathrm{p}}$ value suggests poor reversibility of the electron transfer process. Complexes 3 and 4 are found to be susceptible to conversion to the binary species ${ }^{37}\left[\mathrm{CuB}_{2}\right]^{2+}$ in solution when kept for a longer period of time during crystallization at $30{ }^{\circ} \mathrm{C}$ or above but show significant stability at low temperatures $\left(\mathrm{ca} .4^{\circ} \mathrm{C}\right)$.

Table 1 Selected physicochemical data for the complexes $[\mathrm{Cu}(\mathrm{L}-\mathrm{met}) \mathrm{B}(\mathrm{Solv})]\left(\mathrm{ClO}_{4}\right)(\mathbf{1 - 4})$

\begin{tabular}{|c|c|c|c|c|}
\hline Complex & 1 & 2 & 3 & 4 \\
\hline $\mathrm{IR}^{a}: v\left(\mathrm{ClO}_{4}^{-}\right) / \mathrm{cm}^{-1}$ & 1092 & 1088 & 1084 & 1110 \\
\hline $\mathrm{d}-\mathrm{d}$ band: $\lambda_{\max } / \mathrm{nm}$ & 594 & 609 & 617 & 627 \\
\hline$\left(\varepsilon / \mathrm{dm}^{3} \mathrm{~mol}^{-1} \mathrm{~cm}^{-1}\right)^{\underline{b}}$ & $(90)$ & $(150)$ & $(160)$ & $(180)$ \\
\hline Cyclic voltammetry: & -0.14 & -0.20 & -0.05 & -0.06 \\
\hline
\end{tabular}




\begin{tabular}{|c|c|c|c|c|}
\hline$E_{1 / 2} / \mathrm{V}\left(\Delta E_{\mathrm{p}} / \mathrm{mV}\right)^{\underline{c}}$ & $(430)$ & $(160)$ & $(510)$ & $(460)$ \\
\hline$\Lambda_{\mathrm{M}}{ }^{d} / \Omega^{-1} \mathrm{~cm}^{2} \mathrm{~mol}^{-1}$ & 71 & 68 & 65 & 62 \\
\hline$\mu_{\mathrm{eff}}^{e} / \mu_{\mathrm{B}}$ & 1.78 & 1.82 & 1.78 & 1.86 \\
\hline
\end{tabular}
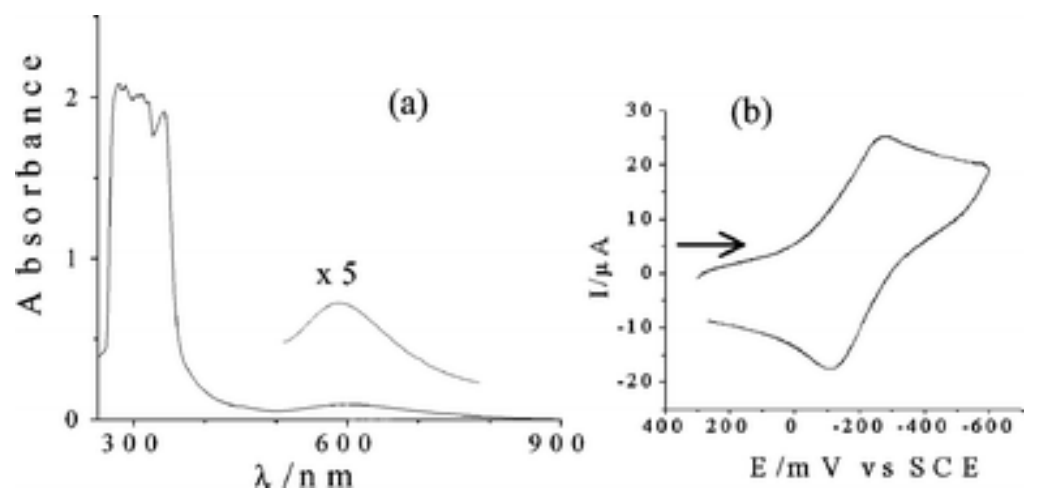

Fig. 1 (a) UV-visible spectrum of 3 in DMF. (b) Cyclic voltammogram of 2 in DMF-Tris buffer at a scan rate of $50 \mathrm{mV} \mathrm{s}^{-1}$.

\section{Crystal structures}

Complex 2 has been characterized from a single-crystal X-ray diffraction study. The crystal structure of the bpy species 1 is reported by Le et al. $\underline{.38}$ The crystal structure of the complexes consist of a monomeric species with the metal ion in a square-pyramidal $(4+1)$ coordination geometry with a $\mathrm{CuN}_{3} \mathrm{O}_{2}$ core (Fig. 2). The donor atoms in the basal plane are two nitrogen atoms of the heterocyclic base (B) and the N,O atoms of L-methionine. The axial site has a coordinated solvent molecule. Complex 2 crystallizes in the monoclinic space group $P 2_{1}$ with two molecules in the crystallographic asymmetric unit. The structural features of $\mathbf{1}$ and $\mathbf{2}$ are essentially the same except that $\mathbf{2}$ has less distortion from the square pyramidal geometry $[\tau=0.08] . \frac{39,40}{}$ Both chiral carbon centers in $\mathbf{2}$ have $S$-configuration. The $a v$. values of the $\mathrm{Cu}-\mathrm{O}$ (basal), $\mathrm{Cu}-\mathrm{O}$ (axial) and $\mathrm{Cu}-\mathrm{N}$ distances are 1.920[6], 2.294[6] and 1.997[7] $\AA$, respectively. The $\mathrm{N}-\mathrm{Cu}-\mathrm{N}$ and $\mathrm{O}-\mathrm{Cu}-\mathrm{N}$ angles involving phen and $\mathrm{L}-\mathrm{met}$ are 82.3[3] and 85.0[3] $]^{\circ}$, respectively. The thiomethyl group in these discrete molecular species does not show any bonding with the metal ion. This group in a metal unbound form could alter the photosensitizing ability of the ligand in comparison to its analogue 2-(thiomethyl)ethylsalicylaldimine (HL) Schiff base in [CuL(phen)] $\left(\mathrm{ClO}_{4}\right)$, where L having a copper-bound thiomethyl group shows efficient red light-induced DNA cleavage activity. $\underline{\underline{16}}$ 


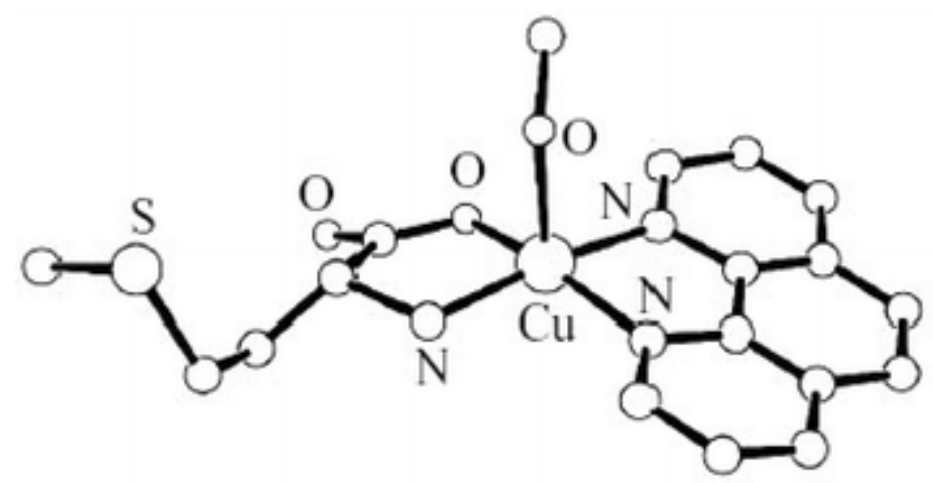

Fig. 2 Perspective view of the cationic complex in $[\mathrm{Cu}(\mathrm{L}-\mathrm{met})(\mathrm{phen})(\mathrm{MeOH})]\left(\mathrm{ClO}_{4}\right)(2)$ with labeling of the heteroatoms.

\section{DNA binding studies}

The binding of the complexes to the calf thymus (CT) DNA has been studied by electronic absorption spectral technique. Binding of a complex to DNA through intercalation usually results in hypochromism and red shift (bathochromic shift) due to the intercalative mode involving a strong stacking interaction between the planar aromatic chromophore and the base pairs of DNA. The extent of the hypochromism in the charge transfer band is commonly consistent with the strength of intercalative binding/interaction. $\frac{41}{}$ The absorption spectral traces of the dppz complex 4 with increasing concentration of CT DNA are shown in Fig. 3a. We have observed a minor bathochromic shift of 1-3 nm along with significant hypochromicity. When the amount of CT DNA is increased, a decrease of $\sim 70 \%$ in the intensity of the charge transfer band is observed. In order to compare the binding strength of the complexes, their intrinsic binding constants $\left(K_{\mathrm{b}}\right)$ with CT-DNA have been determined from the decay of the spectral band absorbance using eqn. (1), where $\varepsilon_{\mathrm{a}}, \varepsilon_{\mathrm{b}}$ and $\varepsilon_{\mathrm{f}}$ are apparent absorption coefficient, $\varepsilon$ of the copper(II) complex in its free form and $\varepsilon$ of the complex in the fully DNA-bound form, respectively (Fig. 3b). $\stackrel{42}{ }$ The $K_{\mathrm{b}}$ values are obtained from the $[\mathrm{DNA}] /\left(\varepsilon_{\mathrm{a}}-\varepsilon_{\mathrm{f}}\right) v s$. [DNA] plots.

$$
[\mathrm{DNA}] /\left(\varepsilon_{\mathrm{a}}-\varepsilon_{\mathrm{f}}\right)=[\mathrm{DNA}] /\left(\varepsilon_{\mathrm{b}}-\varepsilon_{\mathrm{f}}\right)+1 / K_{\mathrm{b}}\left(\varepsilon_{\mathrm{b}}-\varepsilon_{\mathrm{f}}\right)
$$
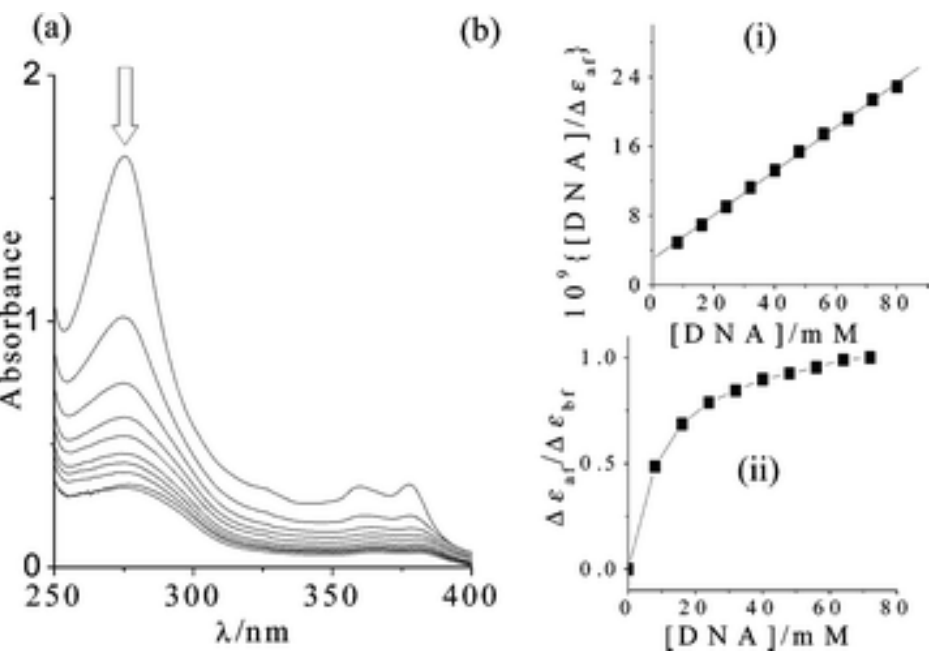

Fig. 3 (a) Absorption spectral changes on addition 
of CT DNA to the solution of $[\mathrm{Cu}(\mathrm{L}-\mathrm{met})(\mathrm{dppz})$

$\left.\left(\mathrm{H}_{2} \mathrm{O}\right)\right]\left(\mathrm{ClO}_{4}\right)(4)$ (shown by arrow). (b) Plots of

[DNA] $/\left(\Delta \varepsilon_{\mathrm{af}}\right) v s$. [DNA] (i) and $\Delta \varepsilon_{\mathrm{af}} / \Delta \varepsilon_{\mathrm{bf}} v s$. [DNA]

(ii), where $\Delta \varepsilon_{\mathrm{af}}=\left(\varepsilon_{\mathrm{a}}-\varepsilon_{\mathrm{f}}\right)$ and $\Delta \varepsilon_{\mathrm{bf}}=\left(\varepsilon_{\mathrm{b}}-\varepsilon_{\mathrm{f}}\right)$.

The intrinsic binding constant $\left(K_{\mathrm{b}}\right)$ values are $2.4 \times 10^{3}, 3.5 \times 10^{3}$ and $8.4 \times 10^{3} \mathrm{M}^{-1}$ for $\mathbf{2 - 4}$, respectively. Complex 4 having dppz ligand with its extended fused aromatic rings shows significantly high binding propensity to DNA. The bpy complex 1, in contrast, does not show any apparent binding to CT DNA. Earlier studies on the bis-phen copper complex have shown that this complex binds to DNA either by partial intercalation or binding of one phen ligand to the minor groove while the other phen makes favourable contacts within the groove. ${ }^{43}$ The nature of binding of the heterocyclic bases in 2-4 is proposed to be similar as observed in the bis-phen species.

The binding of the complexes to the CT DNA has also been studied by fluorescence spectral method using the emission intensity of ethidium bromide (EB) as a probe. ${ }^{44} \mathrm{~EB}$ in a buffer medium shows reduced emission intensity due to quenching by the solvent molecules. It, however, shows significantly enhanced emission intensity when bound to DNA. Binding of the complex to DNA either displaces EB thus decreasing its emission intensity or quenching could take place due to the copper(II) complex in a DNA bound form. We have measured the reduction of the emission intensity of EB at different complex concentration (Fig. S1, see ESI \pm ). The apparent binding constant $\left(K_{\text {app }}\right)$ has been calculated from the equation: $K_{\mathrm{EB}}[\mathrm{EB}]=K_{\mathrm{app}}$ [complex], where $K_{\mathrm{EB}}$ is $1.0 \times 10^{7} \mathrm{M}^{-1}$ and the concentration of $\mathrm{EB}$ is $1.3 \mu \mathrm{M}$. The concentration of the complex is taken for observing $50 \%$ reduction of the emission intensity of EB. $\stackrel{45}{ }$ The $K_{\text {app }}$ values for the complexes are: $1.8 \times 10^{4}, 4.0 \times 10^{4}$ and $6.5 \times 10^{4} \mathrm{M}^{-1}$ for $\mathbf{2}-\mathbf{4}$, respectively.

\section{Chemical nuclease activity}

The oxidative cleavage of DNA in the presence of a reducing agent mercaptopropionic acid (MPA, 5 $\mathrm{mM}$ ) has been studied by gel electrophoresis using supercoiled (SC) pUC19 DNA $(0.5 \mu \mathrm{g})$ in $50 \mathrm{mM}$ Tris-HCl/50 mM NaCl buffer $(14 \mu \mathrm{L}, \mathrm{pH} 7.2)$ treated with the complex (100 $\mu \mathrm{M}$ in $2 \mu \mathrm{L}$ DMF) (Fig. S2, see ESI $\underline{\dagger})$. The chemical nuclease activity follows the order: $\mathbf{3}>\mathbf{4} \geq \mathbf{2} \gg \mathbf{1}$. Control experiments using MPA or $\mathbf{2}$ alone do not show any apparent cleavage of DNA. The poor DNA binder bpy complex $\mathbf{1}$ is cleavage inactive. To understand the DNA cleavage by $\mathbf{2 - 4}$, control experiments are performed in the presence of minor groove binder distamycin. While distamycin does not show any inhibition of cleavage for the dppz complex, it inhibits the cleavage for $\mathbf{2}$ and $\mathbf{3}$. The results suggest major groove binding for the dppz complex and minor groove binding for the other complexes. The observed lower cleavage by the dppz complex 4 with a higher $K_{\mathrm{b}}$ than $\mathbf{3}$ could be related to their different groove binding preferences. Control experiments show that hydroxyl radical scavenger DMSO inhibits the cleavage. The singlet oxygen quencher sodium azide does not show any inhibition.

The pathways involved in the DNA cleavage are believed to be similar to those proposed by Sigman and coworkers for the chemical nuclease activity of bis(phen)copper species (Scheme 2$) .6$ The cleavage efficiencies of the dpq and dppz complexes are likely to differ as the deoxyribose protons abstracted in the cleavage process are different for the DNA major and minor groove. $\frac{1,3-6}{}$ Again, binding of the complex to the DNA is an important aspect for observing chemical nuclease activity. Ternary species $\left[\mathrm{Cu}(\mathrm{L}-\right.$ phe $)($ phen $\left.)\left(\mathrm{H}_{2} \mathrm{O}\right)\right]\left(\mathrm{ClO}_{4}\right)$ having DNA-binder phen shows similar cleavage activity as observed for 2 (Table 2). The thiomethyl group of L-met thus does not play any major role in the chemical nuclease activity. This ligand with a photoactive thiomethyl group is likely to show significant photonuclease activity in comparison to L-phe.

Table 2 Chemical nuclease data ${ }^{a}$ of $1-4$ using $100 \mu \mathrm{M}$ complex and $0.5 \mu \mathrm{g}$ supercoiled pUC19 DNA 


\begin{tabular}{|c|c|c|c|}
\hline Sl. No. & Reaction conditions & Form-I (\%) & Form-II (\%) \\
\hline 1 & DNA control & 92 & 8 \\
\hline 2 & $\mathrm{DNA}+\mathbf{2}$ & 93 & 7 \\
\hline 3 & $\mathrm{DNA}+\mathbf{1}+\mathrm{MPA}$ & 90 & 10 \\
\hline 4 & $\mathrm{DNA}+2+\mathrm{MPA}$ & 60 & 40 \\
\hline 5 & $\mathrm{DNA}+\mathbf{3}+\mathrm{MPA}$ & 17 & 83 \\
\hline 6 & $\mathrm{DNA}+\mathbf{4}+\mathrm{MPA}$ & 53 & 47 \\
\hline 7 & $\mathrm{DNA}+$ distamycin $^{\underline{b}}+\mathbf{3}+\mathrm{MPA}$ & 69 & 31 \\
\hline 8 & $\mathrm{DNA}+$ distamycin ${ }^{\underline{b}}+\mathbf{4}+\mathrm{MPA}$ & 50 & 50 \\
\hline 9 & $\mathrm{DNA}+\mathrm{DMSO}^{c}+\mathbf{3}+\mathrm{MPA}$ & 87 & 13 \\
\hline 10 & $\mathrm{DNA}+\mathrm{NaN}_{3} \frac{d}{+}+\mathbf{3}+\mathrm{MPA}$ & 23 & 77 \\
\hline 11 & $\mathrm{DNA}+\left[\mathrm{Cu}(\mathrm{L}-\right.$ phe $)($ phen $\left.)\left(\mathrm{H}_{2} \mathrm{O}\right)\right]\left(\mathrm{ClO}_{4}\right)^{e}+\mathrm{MPA}$ & 42 & 58 \\
\hline 12 & $\mathrm{DNA}+\mathrm{MPA}$ & 95 & 5 \\
\hline 13 & DNA + L-Methionine ${ }^{e}$ & 94 & 6 \\
\hline
\end{tabular}

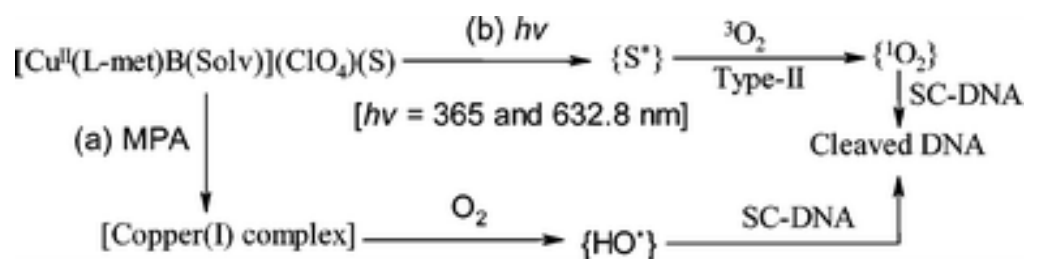

Scheme 2 Proposed mechanistic pathways for the chemical nuclease (a) and photo-induced DNA cleavage (b) reactions involving complexes 1-4 in Tris-buffer medium.

\section{DNA photocleavage activity}

The photo-induced DNA (SC pUC19, $0.5 \mu \mathrm{g}$ ) cleavage experiments were performed in UV (365 nm, 12 $\mathrm{W})$ and visible (632.8 nm, $3 \mathrm{~mW}$ He-Ne CW laser) light using 25-100 $\mu \mathrm{M}$ of the complexes in the absence of any external additive such as MPA. Selected cleavage data are given in Tables 3 and 4 and the gel electrophoresis diagrams are shown in Figs. S3 and S4 (see ESI \pm ). Complex 1 does not show any photonuclease activity at $365 \mathrm{~nm}$. The dpq complex 3 displays $\sim 77 \%$ conversion of the SC (Form I) to its nicked circular form (NC, Form II) of DNA after 5 min exposure. The phen and dppz complexes also show significant cleavage of SC DNA under similar experimental conditions. Control experiments using 3 under dark conditions or L-met alone at $365 \mathrm{~nm}$ do not show any apparent cleavage of SC DNA. Again, the heterocyclic bases dpq or dppz $(50 \mu \mathrm{M})$ alone are cleavage inactive at $365 \mathrm{~nm}$ for an exposure time of $30 \mathrm{~min}$ (Table 3). We have observed complete cleavage of SC DNA by 3 on $30 \mathrm{~min}$ exposure time with a complex concentration of $25 \mu \mathrm{M}$. The photosensitizing ability of L-met in metal bound form is evidenced from the efficient cleavage of the phen complex 2 , while its L-phenylalanine 
analogue $\left[\mathrm{Cu}(\mathrm{L}-\text { phe })(\text { phen })\left(\mathrm{H}_{2} \mathrm{O}\right)\right]^{+}$is cleavage inactive. We have observed from this study that the presence of a photoactive moiety and a DNA binder are a necessary requirement for observing efficient photo-induced DNA cleavage activity. This is evidenced from the facts that while the bpy complex $\mathbf{1}$ is cleavage inactive, complexes $\mathbf{2 - 4}$ are cleavage active. Besides, the amino acid (A) or heterocyclic base (B) is individually cleavage inactive, but their ternary copper(II) complex "A-Cu ${ }^{\mathrm{II}}-\mathrm{B}$ " shows efficient photo-induced DNA cleavage activity. The involvement of the metal center is thus apparent in the metal-assisted DNA cleavage reaction which is likely to involve the ligand-to-metal charge transfer band(s) resulting in photosensitization to the excited singlet state which subsequently via the triplet state activates oxygen to generate reactive singlet oxygen in a type-II process.

Table 3 Photoinduced DNA (SC pUC19, $0.5 \mu \mathrm{g}$ ) cleavage data ${ }^{a}$ of the complexes 1-4 using UV radiation of $365 \mathrm{~nm}(12 \mathrm{~W})$ using a complex concentration of $50 \mu \mathrm{M}$

\begin{tabular}{|c|c|c|c|c|}
\hline Sl. No. & Reaction conditions & $t^{\underline{b}}$ & Form-I (\%) & Form-II (\%) \\
\hline 1 & DNA control & 5 & 96 & 4 \\
\hline 2 & $\mathrm{DNA}+\mathbf{3}$ in dark & 5 & 94 & 6 \\
\hline 3 & $\mathrm{DNA}+\mathrm{dpq}(50 \mu \mathrm{M})$ & 5 & 93 & 7 \\
\hline 4 & DNA + L-methionine $(50 \mu \mathrm{M})$ & 5 & 94 & 6 \\
\hline 5 & $\mathrm{DNA}+\mathbf{1}$ & 5 & 90 & 10 \\
\hline 6 & $\mathrm{DNA}+2$ & 5 & 60 & 40 \\
\hline 7 & $\mathrm{DNA}+4$ & 5 & 40 & 60 \\
\hline 8 & $\mathrm{DNA}+\mathbf{3}$ & 5 & 23 & 77 \\
\hline 9 & $\mathrm{DNA}+\mathrm{NaN}_{3} \frac{c}{+} \mathbf{3}$ & 5 & 87 & 13 \\
\hline 10 & $\mathrm{DNA}+\mathrm{D}_{2} \mathrm{O}^{d}+\mathbf{3}$ & 5 & 16 & 84 \\
\hline 11 & $\mathrm{DNA}+\mathrm{DMSO}^{e}+\mathbf{3}$ & 5 & 28 & 72 \\
\hline 12 & $\mathrm{DNA}+\mathbf{3}(25 \mu \mathrm{M})$ & 30 & 10 & 90 \\
\hline 13 & $\mathrm{DNA}+\left[\mathrm{Cu}(\mathrm{L}-\right.$ phe $)($ phen $\left.)\left(\mathrm{H}_{2} \mathrm{O}\right)\right]\left(\mathrm{ClO}_{4}\right)^{f}$ & 5 & 93 & 7 \\
\hline 14 & $\mathrm{DNA}+\mathrm{dpq}(50 \mu \mathrm{M})$ & 30 & 91 & 9 \\
\hline 15 & $\mathrm{DNA}+\mathrm{dppz}(50 \mu \mathrm{M})$ & 30 & 94 & 6 \\
\hline \multicolumn{5}{|r|}{ M. $\quad 14 \mu \mathrm{L}$. } \\
\hline
\end{tabular}

Table 4 Red light-induced DNA (SC pUC19, $0.5 \mu \mathrm{g}$ ) cleavage data ${ }^{a}$ of the complexes $\mathbf{2}-\mathbf{4}$ at $632.8 \mathrm{~nm}$ $(3 \mathrm{~mW})$ for an exposure time of $1 \mathrm{~h}$ using a complex concentration of $100 \mu \mathrm{M}$

\begin{tabular}{|c|c|c|c|}
\hline Sl. No. & Reaction conditions & Form-I (\%) & Form-II (\%) \\
\hline 1 & DNA Control & 95 & 5 \\
\hline 2 & DNA + dpq $(100 \mu \mathrm{M})$ & 92 & 8 \\
\hline 3 & $\mathrm{DNA}+\mathbf{3}$ in dark & 93 & 7 \\
\hline 4 & $\mathrm{DNA}+2$ & 68 & 32 \\
\hline
\end{tabular}




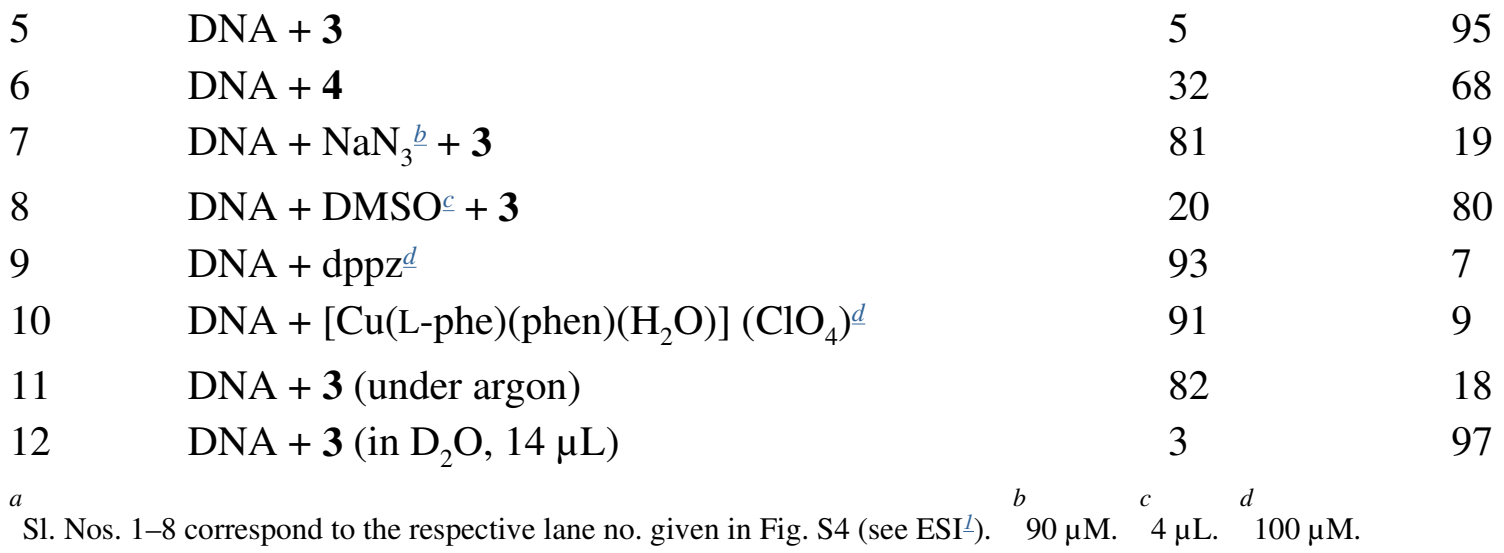

The complexes are found to be photo-cleavage inactive in the presence of singlet oxygen quencher sodium azide. Significant enhancement of cleavage is observed in $\mathrm{D}_{2} \mathrm{O}$ solvent in which singlet oxygen has a longer lifetime. $\frac{46}{6}$ Hydroxyl radical scavenger DMSO does not show any inhibitory effect. Control experiment data indicate the formation of singlet oxygen on photoexposure at $365 \mathrm{~nm}$. In complex 2, the L-met acts as a photosensitizer, while phen is the DNA minor groove binder. For the dpq and dppz complexes, the DNA binder heterocyclic bases have photoactive quinoxaline and phenazine moieties, thus giving additional metal-assisted photosensitization effect enhancing the cleavage activity. Our observation of higher cleavage activity of $\mathbf{3}$ than $\mathbf{4}$ could be due to their different groove binding preference and for the reduced triplet state lifetime of the phenazine moiety in the presence of fused aromatic rings.

We have explored the photocleavage activity of the complexes $\mathbf{2 - 4}$ at red light of $632.8 \mathrm{~nm}$ from a low power $\mathrm{CW} \mathrm{He}-\mathrm{Ne}$ laser source using a complex concentration of $100 \mu \mathrm{M}$ with a longer exposure time (Table 4, Fig. S4, see ESI $\underline{\dagger}$ ). This wavelength happens to be close to the one used for photoactivation of Photofrin ${ }^{\circledR}$ and the $d-d$ band observed for these ternary complexes. The phen complex shows $\sim 30 \%$ cleavage of SC DNA to its NC form. Under similar reaction conditions, the dpq complex displays essentially complete cleavage of SC DNA while its dppz analogue shows $\sim 70 \%$ cleavage activity (Fig. 4). The results are of importance as the ligands alone are cleavage inactive at this wavelength. Addition of sodium azide is found to inhibit the cleavage, while DMSO shows no apparent inhibition. The complexes are cleavage inactive under an argon atmosphere indicating the involvement of oxygen in the cleavage reaction (Table 4). This is indicative of a type-II process which is similar to that observed at $365 \mathrm{~nm}$ forming singlet oxygen $\left(\mathrm{O}_{2},{ }^{1} \Delta_{g}\right)$ as the reactive species (Scheme 2). We have earlier reported the red light-induced DNA cleavage activity of a ternary mono-phen copper(II) complex containing a Schiff base with a metal-bound thiomethyl group involving the formation of singlet oxygen species. $\frac{16}{}$ In contrast, the binary copper(II) complex $\left[\mathrm{Cu}(\mathrm{dpq})_{2}\right]^{2+}$ shows DNA cleavage at red light via a

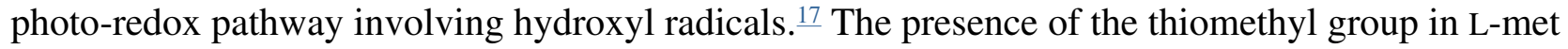
could be responsible for the type-II process to be operative in preference to the photo-redox pathway. Further studies are in progress to determine the role of the pendant -SMe moiety in the overall photosensitization process in conjunction with the heterocyclic base. 


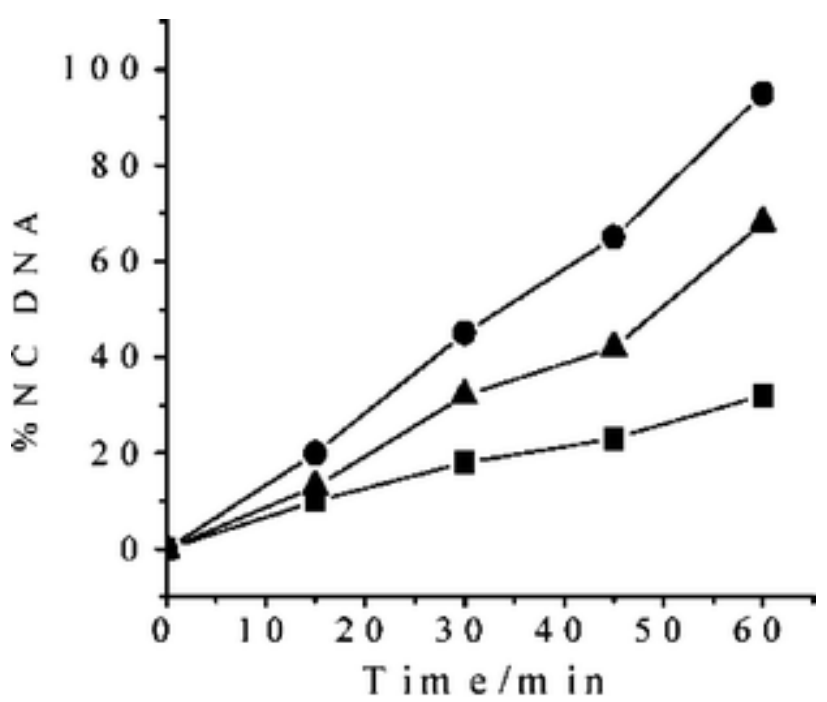

Fig. 4 The extent of red light-induced cleavage of SC DNA $(0.5 \mu \mathrm{g})$ for the complexes $2(\boldsymbol{\square}) 3(\bullet)$ and $\mathbf{4}(\boldsymbol{\Lambda})$ at different exposure times $[\lambda=632.8 \mathrm{~nm} \mathrm{CW}$ laser $(3 \mathrm{~mW})$; complex concentration $=100 \mu \mathrm{M}]$.

\section{Conclusion}

Four L-methionine copper(II) complexes having N,N-donor heterocyclic bases (B) are prepared and structurally characterized. In the $\left[\mathrm{L}-\mathrm{met}-\mathrm{Cu}^{\mathrm{II}}-\mathrm{B}\right]^{+}$ternary structure, the bidentate amino acid with a thiomethyl pendant group acts as a photosensitizer and the planar heterocyclic bases like phen, dpq and dppz are DNA groove binders. The dpq and dppz ligands also show photosensitization ability when bound to the copper(II) ion. The bpy complex does not show any apparent binding to DNA and is cleavage inactive. The other three complexes show efficient chemical and photonuclease activity. While the dppz complex is a major groove binder, its analogues show minor groove binding preference. The chemical nuclease activity in the presence of a reducing agent involves formation of the hydroxyl radical or reactive copper-oxo species. The photonuclease activity at $365 \mathrm{~nm}$ or red light of $632.8 \mathrm{~nm}$ wavelength involves a type-II process with the formation of reactive singlet oxygen. The cleavage efficiency of the dpq complex is significantly higher than its dppz analogue. This work provides evidence for the involvement of $\mathrm{d}^{9}-\mathrm{Cu}$ (II) in the photosensitization process as the UV photoactive ligands alone are cleavage inactive at the wavelengths used in our study. The results are of significance in designing new transition metal-based non-porphyrinic amino acid/peptide complexes suitable for DNA cleavage in the PDT window of 600-800 $\mathrm{nm}$ and for cellular applications.

\section{Experimental}

\section{Materials}

All reagents and chemicals were procured from commercial sources and used without further purification. The supercoiled (SC) pUC19 DNA (caesium chloride purified) was purchased from Bangalore Genie (India). The calf thymus (CT) DNA, agarose (molecular biology grade), distamycin and ethidium bromide (EB) were obtained from Sigma. Tris(hydroxymethyl)-aminomethane-HCl (Tris$\mathrm{HCl}$ ) buffer was prepared using deionized and sonicated triple distilled water. Solvents used for electrochemical and spectroscopic studies were purified and dried by standard procedures before use. ${ }^{47}$

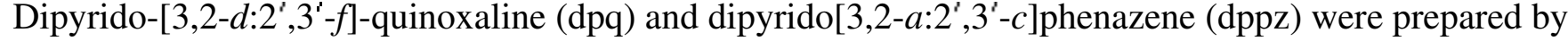
literature procedures. $\stackrel{48}{ }$ Complex $\left[\mathrm{Cu}(\mathrm{L}-\mathrm{phe})(\mathrm{phen})\left(\mathrm{H}_{2} \mathrm{O}\right)\right]\left(\mathrm{ClO}_{4}\right)$ was prepared by a literature method. $\frac{36}{6}$ 


\section{Physical measurements}

The elemental analysis was performed using a Thermo Finnigan FLASH EA 1112 CHNS analyzer. The infrared, electronic and fluorescence spectra were recorded on Perkin-Elmer Lambda 35, Perkin Elmer spectrum one 55 and Perkin-Elmer LS 50B spectrophotometers, respectively. Room-temperature magnetic susceptibility data at $298 \mathrm{~K}$ for polycrystalline samples were obtained using a Model 300 Lewis-coil-force magnetometer from George Associates Inc. (Berkeley, USA). Hg[Co(NCS) ${ }_{4}$ ] was used as a calibrant. Experimental susceptibility data were corrected for diamagnetic contributions. ${ }^{49}$ Molar conductivity measurements were performed using a Control Dynamics (India) conductivity meter. Cyclic voltammetric measurements were made at $25^{\circ} \mathrm{C}$ on an EG\&G PAR model 253 VersaStat potentiostat/galvanostat with electrochemical analysis software 270 using a three electrode set-up comprising a glassy carbon working, platinum wire auxiliary and a saturated calomel reference electrode (SCE) in DMF-Tris buffer medium.

\section{Synthesis of $[\mathrm{Cu}(\mathrm{L}-\mathrm{met}) \mathrm{B}(\mathrm{Solv})]\left(\mathrm{ClO}_{4}\right)(1-4)$}

The complexes were prepared by a general synthetic method in which a mixture of L-methionine $(0.75$ $\mathrm{g}, 5 \mathrm{mmol})$ and $\mathrm{NaOH}(0.2 \mathrm{~g}, 5 \mathrm{mmol})$ in $10 \mathrm{~cm}^{3}$ water was added to an aqueous solution $\left(25 \mathrm{~cm}^{3}\right) \mathrm{of}$ $\mathrm{CuSO}_{4} \cdot 5 \mathrm{H}_{2} \mathrm{O}(1.25 \mathrm{~g}, 5 \mathrm{mmol})$ with stirring for $30 \mathrm{~min}$ followed by addition of the corresponding heterocyclic base [bpy, 1; phen, 2; dpq, 3; dppz, 4 (5 mmol)] taken in $10 \mathrm{~cm}^{3}$ of methanol. The solution was stirred for $2 \mathrm{~h}$ with heating at $60^{\circ} \mathrm{C}$. On completion of the reaction, an aqueous solution of $\mathrm{NaClO}_{4}$ $(0.6 \mathrm{~g}, 5 \mathrm{mmol})$ was added to the filtrate of the reaction mixture. Slow evaporation of the solvent at room temperature yielded a crystalline solid of the product (dark blue for 1, 2; greenish colour for 3, 4). Yield: $\sim 70 \%$. Anal. Calcd. for $\mathrm{C}_{15} \mathrm{H}_{20} \mathrm{~N}_{3} \mathrm{ClO}_{7} \mathrm{SCu}(1)$ : C, 37.1; H, 4.2; N, 8.7\%. Found: C, 36.8; H, 4.1; $\mathrm{N}, 8.3 \%$. IR $\left(\mathrm{KBr}, \mathrm{cm}^{-1}\right)$ : 3424br, 3335w, 3316w, 3255w, 3085w, 2967w, 2913w, 1602m, 1569s, $1496 \mathrm{~m}, 1473 \mathrm{~m}, 1444 \mathrm{~s}, 1319 \mathrm{~m}, 1252 \mathrm{~m}, 1092 \mathrm{vs}, 813 \mathrm{w}, 771 \mathrm{~s}, 730 \mathrm{~m}, 662 \mathrm{~m}, 623 \mathrm{~m}, 569 \mathrm{~s}, 441 \mathrm{w}, 416 \mathrm{~m}$. (br, broad; w, weak; m, medium; s, strong; $v$, very strong). UV-visible $\left[\left(\lambda_{\max }, \mathrm{nm}\left(\varepsilon, \mathrm{dm}^{3} \mathrm{~mol}^{-1} \mathrm{~cm}^{-1}\right)\right]\right.$ in DMF: 594 (90); 301(12550); 312 (11900). Anal. Calcd. for $\mathrm{C}_{18} \mathrm{H}_{22} \mathrm{~N}_{3} \mathrm{ClO}_{7} \mathrm{SCu}$ (2): C, 41.3; H, 4.2; N, 8.0\%. Found: C, 41.1; H, 4.0; N, 8.1\%. IR (KBr, cm $\left.{ }^{-1}\right): 3436 \mathrm{br}, 3327 \mathrm{~m}, 3284 \mathrm{~m}, 3241 \mathrm{w}, 3161 \mathrm{w}, 3058 \mathrm{w}$, 2935w, 2909w, 2838w, 1636s, 1519m, 1428m, 1387m, 1342w, 1315w, 1088vs, 622s, 614s, 564s. UVvisible $\left[\left(\lambda_{\max }, \mathrm{nm}\left(\varepsilon, \mathrm{dm}^{3} \mathrm{~mol}^{-1} \mathrm{~cm}^{-1}\right)\right]\right.$ in DMF: 609 (150); 275 (32740); 294(sh) (16800). Anal. Calcd. for $\mathrm{C}_{19} \mathrm{H}_{20} \mathrm{~N}_{5} \mathrm{ClO}_{7} \mathrm{SCu}(3)$ : C, 39.8; H, 3.5; N, 12.2\%. Found: C, 40.1; H, 3.4; N, 11.9\%. IR $\left(\mathrm{KBr}, \mathrm{cm}^{-1}\right)$ : 3437br, 3307w, 3084w, 2918m, 1646m, 1609s, 1485m, 1412w, 1391m, 1341w, 1307w, 1277m, 1213s, 1084vs, 821s, 732s, 624s, 553m, 437m. UV-visible $\left[\left(\lambda_{\max }, \mathrm{nm}\left(\varepsilon, \mathrm{dm}^{3} \mathrm{~mol}^{-1} \mathrm{~cm}^{-1}\right)\right]\right.$ in DMF: $617(160)$; 338 (6330). Anal. Calcd. for $\mathrm{C}_{23} \mathrm{H}_{22} \mathrm{~N}_{5} \mathrm{ClO}_{7} \mathrm{SCu}(4)$ : C, 45.2; H, 3.6; N, 11.4\%. Found: C, 45.3; H, 3.9; $\mathrm{N}, 11.5 \%$. IR $\left(\mathrm{KBr}, \mathrm{cm}^{-1}\right): 3405 \mathrm{br}, 3298 \mathrm{w}, 3240 \mathrm{w}, 3077 \mathrm{w}, 2368 \mathrm{w}, 1619 \mathrm{~s}, 1569 \mathrm{~m}, 1500 \mathrm{~m}, 1422 \mathrm{~m}$, $1402 \mathrm{~m}, 1359 \mathrm{~m}, 1110 \mathrm{vs}, 817 \mathrm{~m}, 766 \mathrm{~m}, 732 \mathrm{~m}, 619 \mathrm{~s}, 577 \mathrm{~s}, 422 \mathrm{~m}$. UV-visible $\left[\left(\lambda_{\max }, \mathrm{nm}\left(\varepsilon, \mathrm{dm}^{3} \mathrm{~mol}^{-1}\right.\right.\right.$ cm ${ }^{-1}$ )] in DMF: 627 (180); 420sh (5500); 380 (9900); 300 (10600).

Caution! Perchlorate salts of metal complexes containing organic ligands are potentially explosive and only small quantities were handled with care.

Solubility and stability. The complexes were found to be soluble in DMF, DMSO, moderately soluble in alcoholic medium and sparingly soluble in water.

\section{X-Ray crystallographic procedures}

Crystal data for 2: $\mathrm{C}_{18} \mathrm{H}_{22} \mathrm{ClCuN}_{3} \mathrm{O}_{7} \mathrm{~S}, M=523.44$, monoclinic $P 2_{1}$ (no. 4), $a=9.246(4), b=20.531(9)$, $c=11.864(5) \AA, \beta=96.985(8)^{\circ}, U=2235.4(17) \AA, Z=4, D_{\mathrm{c}}=1.555 \mathrm{~g} \mathrm{~cm}^{-3}, T=293(2) \mathrm{K}, \lambda=$ 
$0.71073 \AA, 1.73 \leq \theta \leq 26.07^{\circ}, \mu=12.34 \mathrm{~cm}^{-1}, F(000)=1076$.

Single crystals of $[\mathrm{Cu}(\mathrm{L}-\mathrm{met})(\mathrm{phen})(\mathrm{MeOH})]\left(\mathrm{ClO}_{4}\right)(2)$ were obtained from an aqueous methanolic solution of the complex. Crystal mounting was done on glass fibre with epoxy cement. All geometric and intensity data were collected at room temperature using an automated Bruker SMART APEX CCD diffractometer equipped with a fine focus $1.75 \mathrm{~kW}$ sealed tube Mo-K $\mathrm{K}_{\alpha}$-ray source $(\lambda=0.71073 \AA)$ with increasing $\omega$ (width of $0.3^{\circ}$ per frame) at a scan speed of $12 \mathrm{~s}$ per frame. Intensity data were corrected for Lorentz-polarization effects and for absorption. $\underline{50}$ The structure was solved and refined with the SHELX system of programs. $\frac{51}{5}$ The hydrogen atoms attached to the carbons were fixed in their calculated positions and refined using a riding model. All non-hydrogen atoms were refined anisotropically. The full-matrix least squares refinement converged to $R 1=0.0534, w R 2=0.1329$ for 5323 reflections with $I>2 \sigma(I)$ and 567 parameters [ $R 1$ (all data) $=0.0872$ ], weighting scheme: $w=1 /[$ $\left.\sigma^{2}\left(F_{\mathrm{o}}{ }^{2}\right)+(0.0894 P)^{2}+0.0 P\right]$ where $P=\left[F_{\mathrm{o}}{ }^{2}+2 F_{\mathrm{c}}{ }^{2}\right] / 3$. The goodness-of-fit and the largest difference peak were 0.947 and 0.633 e $\AA^{-3}$, respectively. Perspective view of the complex was obtained by ORTEP 52 (See ESI

CCDC reference numbers 207304 and 254360.

See http://www.rsc.org/suppdata/dt/b4/b416711b/ for crystallographic data in CIF or other electronic format.

\section{DNA binding and cleavage experiments}

The DNA binding experiments were carried out in Tris- $\mathrm{HCl}$ buffer $(50 \mathrm{mM}$ Tris- $\mathrm{HCl}, \mathrm{pH} 7.2)$ using the complex solution in DMF. A solution of calf thymus (CT) DNA (ca. $350 \mu \mathrm{M} \mathrm{NP}$ ) in the buffer gave a ratio of UV absorbance at 260 and $280 \mathrm{~nm}$ of $c a .1 .9: 1$ indicating that the DNA was sufficiently free from protein. $\frac{53}{5}$ The concentration of DNA was determined from its absorption intensity at $260 \mathrm{~nm}$ with a known molar absorption coefficient value of $6600 \mathrm{dm}^{3} \mathrm{~mol}^{-1} \mathrm{~cm}^{-1} . \underline{54}$ Absorption titration experiments were performed by varying the concentration of the CT DNA with the metal complex concentration of $40 \mu \mathrm{M}$. Due correction had been made to eliminate the absorbance of DNA itself. All UV-spectra were recorded after equilibration. The intrinsic binding constant $K_{\mathrm{b}}$ was determined from a plot of [DNA]/( $\varepsilon_{\mathrm{a}}$ $\left.-\varepsilon_{\mathrm{f}}\right) v s$. [DNA] (eqn. (1)). The apparent binding constant $\left(K_{\text {app }}\right)$ of the complexes were determined by a fluorescence spectral technique using ethidium bromide (EB) bound CT DNA solution in Tris$\mathrm{HCl} / \mathrm{NaCl}$ buffer ( $\mathrm{pH}, 7.2)$. The fluorescence intensities at $600 \mathrm{~nm}$ (546 nm excitation) of EB with an increasing amount of the ternary complex concentration were recorded. Ethidium bromide was nonemissive in Tris-buffer medium due to fluorescence quenching of the free EB by the solvent molecules. In the presence of DNA, EB showed enhanced emission intensity due to its intercalative binding to DNA. A competitive binding of the copper complexes to CT DNA resulted in the displacement or quenching of the bound EB decreasing its emission intensity.

The extent of SC pUC19 DNA cleavage was monitored by agarose gel electrophoresis. The SC DNA $(0.5 \mu \mathrm{g})$ in $50 \mathrm{mM}$ tris(hydroxymethyl)methane- $\mathrm{HCl}$ (Tris- $\mathrm{HCl}$ ) buffer (pH 7.2) containing $50 \mathrm{mM} \mathrm{NaCl}$ was treated with the metal complex $(25-100 \mu \mathrm{M}, 2 \mu \mathrm{L}$ in DMF) followed by dilution with the buffer to a total volume of $18 \mu \mathrm{L}$. For photo-induced DNA cleavage studies, the reactions were carried out under illuminated conditions using UV source of $365 \mathrm{~nm}(12 \mathrm{~W})$ or low powered CW He-Ne laser of 632.8 $\mathrm{nm}$ (Scientifica-Cook make, UK, $3 \mathrm{~mW}$ ). After exposure to the light, each sample was incubated for $1 \mathrm{~h}$ at $37^{\circ} \mathrm{C}$ in the dark and analyzed using gel electrophoresis. The inhibition reactions were carried out by adding reagents (distamycin, $75 \mu \mathrm{M}$; DMSO, $4 \mu \mathrm{L}$; sodium azide, $90 \mu \mathrm{M}$ ) prior to the addition of the complex. For the $\mathrm{D}_{2} \mathrm{O}$ experiment, this solvent was used for dilution to $18 \mu \mathrm{L}$. Eppendorf and glass vials were used for the UV and visible light experiments, respectively, at $25{ }^{\circ} \mathrm{C}$ in a dark room. The samples after incubation were added to the loading buffer containing $25 \%$ bromophenol blue, $0.25 \%$ xylene cyanol, $30 \%$ glycerol $(3 \mu \mathrm{L})$ and the solution was finally loaded on $0.8 \%$ agarose gel containing $1.0 \mu \mathrm{g}$ $\mathrm{mL}^{-1}$ ethidium bromide. Electrophoresis was carried out in a dark chamber for $2 \mathrm{~h}$ at $60 \mathrm{~V}$ in TAE (Trisacetate EDTA) buffer. Bands were visualized by UV light and photographed. The extent of DNA 
cleavage was measured from the intensities of the bands using UVITEC Gel Documentation System. Due corrections were made for the low level of nicked circular (NC) form present in the original supercoiled (SC) DNA sample and for the low affinity of EB binding to SC compared to its NC form..$\underline{55}$ The concentration of the complex and additives corresponded to the quantity of the sample in $2 \mu \mathrm{L}$ stock solution used. The final concentration was one ninth of the given concentration as the stock solution was diluted with buffer to $18 \mu \mathrm{L}$ after addition of $0.8 \mu \mathrm{L}$ SC DNA solution.

\section{Acknowledgements}

We thank the Council of Scientific and Industrial Research (CSIR), New Delhi, and the Department of Science and Technology (DST), Government of India, for financial support; DST for the CCD diffractometer facility; Alexander von Humboldt Foundation, Germany, for donation of an electroanalytical system, and the Convener, Bioinformatics Center of our Institute, for database search. AKP is thankful to CSIR for a fellowship.

\section{References}

1 (a) A. M. Pyle and J. K. Barton, Prog. Inorg. Chem., 1990, 38, 413 [Links]; (b) K. E. Erkkila, D. T. Odom and J. K. Barton, Chem. Rev., 1999, 99, 2777 [Links]; (c) J. K. Barton, Science, 1986, 233, 727 [Links]; (d) J. K. Barton and A. L. Raphael, Proc. Natl. Acad. Sci. USA, 1985, 82, 6460 [Links].

2 (a) B. Armitage, Chem. Rev., 1998, 98, 1171 [Links]; (b) D. R. McMillin and K. M. McNett, Chem. Rev., 1998, 98, 1201 [Links]; (c) C. Metcalfe and J. A. Thomas, Chem. Soc. Rev., 2003, 32, 215 [Links].

3 (a) B. Meunier, Chem. Rev., 1992, 92, 1411 [Links]; (b) G. Pratviel, J. Bernadou and B. Meunier, Adv. Inorg. Chem., 1998, 45, 251 [Links]; (c) G. Pratviel, J. Bernadou and B. Meunier, Angew. Chem., Int. Ed. Engl., 1995, 34, 746 [Links].

4 W. K. Pogozelski and T. D. Tullius, Chem. Rev., 1998, 98, 1089 [Links].

5 C. J. Burrows and J. G. Muller, Chem. Rev., 1998, 98, 1109 [Links].

6 (a) O. Zelenko, J. Gallagher and D. S. Sigman, Angew. Chem., Int. Ed. Engl., 1997, 36, 2776 [Links]; (b) D. S. Sigman, T. W. Bruice, A. Mazumder and C. L. Sutton, Acc. Chem. Res., 1993, 26, 98 [Links]; (c) D. S. Sigman, A. Mazumder and D. M. Perrin, Chem. Rev., 1993, 93, 2295 [Links];

(d) D. S. Sigman, Acc. Chem. Res., 1986, 19, 180 [Links]; (e) D. S. Sigman, Biochemistry, 1990, 29, 9097 [Links]; $(f)$ L. E. Marshall, D. R. Graham, K. A. Reich and D. S. Sigman, Biochemistry, 1981, 20, 244 [Links]; (g) D. S. Sigman, D. R. Graham, V. D'Aurora and A. M. Stern, J. Biol. Chem., 1979, 254, 12269 [Links].

7 (a) S. J. Lippard, Biochemistry, 2003, 42, 2664 [Links]; (b) E. R. Jamieson and S. J. Lippard, Chem. Rev., 1999, 99, 2467 [Links].

8 (a) E. L. Hegg and J. N. Burstyn, Coord. Chem. Rev., 1998, 173, 133 [Links]; (b) J. Reedijk, J. Inorg. Biochem., 2001, 86, 89.

9 (a) S. E. Wolkenberg and D. L. Boger, Chem. Rev., 2002, 102, 2477 [Links]; (b) A. Sreedhara and J. A. Cowan, J. Biol. Inorg. Chem., 2001, 6, 337.

10 H. Ali and J. E. Van Lier, Chem. Rev., 1999, 99, 2379 [Links].

11 (a) R. Bonnett, Chem. Soc. Rev., 1995, 24, 19 [Links]; (b) T. J. Dougherty, C. J. Gomer, B. W. Henderson, G. Jori, D. Kessel, M. Korbelik, J. Moan and Q. Peng, J. Natl. Cancer Inst., 1998, 90, 889 [Links].

12 (a) R. Ackroyd, C. Kelty, N. Brown and M. Reed, Photochem. Photobiol., 2001, 74, 656 [Links];

(b) B. W. Henderson and T. J. Dougherty, Photochem. Photobiol., 1992, 55, 145 [Links]. 
13 (a) M. C. De Rosa and R. J. Crutchley, Coord. Chem. Rev., 2002, 233/4, 351 [Links]; (b) E. D. Sternberg, D. Dolphin and C. Brückner, Tetrahedron, 1998, 54, 4151 [Links].

14 J. L. Sessler, G. Hemmi, T. D. Mody, T. Murai, A. Burrell and S. W. Young, Acc. Chem. Res., 1994, 27, 43 [Links].

15 B. W. Henderson, T. M. Busch, L. A. Vaughan, N. P. Frawley, D. Babich, T. A. Sosa, J. D. Zollo, A. S. Dee, M. T. Cooper, D. A. Bellnier, W. R. Greco and A. R. Oseroff, Cancer Res., 2000, 60, 525 [Links].

16 (a) S. Dhar, D. Senapati, P. K. Das, P. Chattopadhyay, M. Nethaji and A. R. Chakravarty, J. Am. Chem. Soc., 2003, 125, 12118 [Links]; (b) S. Dhar and A. R. Chakravarty, Inorg. Chem., 2003, 42, 2483 [Links].

17 S. Dhar, D. Senapati, P. A. N. Reddy, P. K. Das and A. R. Chakravarty, Chem. Commun., 2003, 2452 [Links].

18 A. M. Thomas, M. Nethaji and A. R. Chakravarty, J. Inorg. Biochem., 2004, 98, 1087 [Links].

19 P. A. N. Reddy, B. K. Santra, M. Nethaji and A. R. Chakravarty, J. Inorg. Biochem., 2004, 98, 377 [Links].

20 (a) A. M. Thomas, A. D. Naik, M. Nethaji and A. R. Chakravarty, Inorg. Chim. Acta, 2004, 357/8, 2315 [Links]; (b) A. M. Thomas, A. D. Naik, M. Nethaji and A. R. Chakravarty, Indian J. Chem., 2004, 43A, 691.

21 R. Ren, P. Yang, W. Zheng and Z. Hua, Inorg. Chem., 2000, 39, 5454 [Links].

22 Á. G-. Raso, J. J. Fiol, B. Adrover, V. Moreno, I. Mata, E. Espinosa and E. Molins, J. Inorg. Biochem., 2003, 95, 77 [Links].

23 D. C. A. John and K. T. Douglas, Biochem. J., 1993, 289, 463 [Links].

24 D. Herebian and W. S. Sheldrick, J. Chem. Soc., Dalton Trans., 2002, 966 [Links].

25 C.-T. Cheng, V. Lo, J. Chen, W.-C. Chen, C.-Y. Lin, H.-C. Yang and L. Sheh, Bioorg. Med. Chem., 2001, 9, 1493 [Links].

26 T. K. Roger, T. W. Joel and J. F. Sonya, J. Am. Chem. Soc., 2003, 125, 6656 [Links].

27 K. P. Mahon, Jr., R. F. Ortiz-Meoz, E. G. Prestwich and S. O. Kelley, Chem. Commun., 2003, 1956 [Links].

28 I. Saito and M. Takayama, J. Am. Chem. Soc., 1995, 117, 5590 [Links].

29 K. Toshima, R. Takano, T. Ozawa and S. Matsumura, Chem. Commun., 2002, 212 [Links].

30 X. Qian, T.-B. Huang, D.-Z. Wei, D.-H. Zhu, M.-C. Fan and W. Yao, J. Chem. Soc., Perkin Trans., 2, 2000, 715 [Links].

31 (a) A. Jakobs and J. Piette, J. Photochem. Photobiol. B, 1994, 22, 9 [Links]; (b) A. Jakobs and J. Piette, J. Med. Chem., 1995, 38, 869 [Links]; (c) A. Seret, J. Piette, A. Jakobs and A. Van de Vorst, Photochem. Photobiol., 1992, 56, 409 [Links].

32 A. K. Patra, S. Dhar, M. Nethaji and A. R. Chakravarty, Chem. Commun., 2003, 1562 [Links].

33 R. E. Holmlin, E. D. A. Stemp and J. K. Barton, Inorg. Chem., 1998, 37, 29 [Links].

34 R. H. Terbrueggen, T. W. Johann and J. K. Barton, Inorg. Chem., 1998, 37, 6874 [Links].

35 S. Dhar, P. A. N. Reddy, M. Nethaji, S. Mahadevan, M. K. Saha and A. R. Chakravarty, Inorg. Chem., 2002, 41, 3469 [Links].

36 P. S. Subramanian, E. Suresh, P. Dastidar, S. Waghmode and D. Srinivas, Inorg. Chem., 2001, 40, 4291 [Links].

37 (a) T. Gupta, S. Dhar, M. Nethaji and A. R. Chakravarty, Dalton Trans., 2004, 1896 [Links]; (b) B. K. Santra, P. A. N. Reddy, G. Neelakanta, S. Mahadevan, M. Nethaji and A. R. Chakravarty, J. Inorg. Biochem., 2002, 89, 191 [Links]. 
38 X.-Y. Le, M.-L. Tong, Y.-L. Fu and L.-N. Ji, Chin. J. Chem., 2003, 21, 44 [Links].

39 X.-Y. Le and M.-L. Tong, Chin. J. Inorg. Chem., 2002, 18, 1023.

40 A. W. Addison, T. N. Rao, J. V. Reedijk and G. C. Verschoor, J. Chem. Soc., Dalton Trans., 1984, 1349 [Links].

41 (a) A. Ambroise and B. G. Maiya, Inorg. Chem., 2000, 39, 4264 [Links]; (b) A. Tysoe, R. J. Morgan, A. D. Baker and T. C. Strekas, J. Phys. Chem., 1993, 97, 1707 [Links]; (c) J. K. Barton, A. T. Danishefsky and J. M. Goldberg, J. Am. Chem. Soc., 1984, 106, 2172 [Links]; (d) T. M. Kelly, A. B. Tossi, D. J. McConnel and T. C. Strekas, Nucleic Acid Res., 1985, 13, 6017 [Links].

42 A. Wolfe, G. H. Shimer and T. Meehan, Biochemistry, 1987, 26, 6392 [Links].

43 (a) M. Pitié, J. D. V. Horn, D. Brion, C. J. Burrows and B. Meunier, Bioconjugate Chem., 2000, 11, 892 [Links]; (b) J. M. Veal, K. Merchant and R. L. Rill, Nucleic Acids Res., 1991, 19, 338; (c) J. M. Veal and R. L. Rill, Biochemistry, 1991, 30, 1132 [Links]; (d) J. M. Veal and R. L. Rill,

Biochemistry, 1988, 27, 1822 [Links]; (e) L. D. Williams, J. Thivierge and I. H. Goldberg, Nucleic Acids Res., 1988, 16, 11607 [Links]; (f) J. C. Stockert, J. Theor. Biol., 1989, 137, 107 [Links]; $(g)$ O. Baudoin, M.-P. Teulade-Fichou, J.-P. Vigneron and J.-M. Lehn, Chem. Commun., 1998, 2349 [Links].

44 (a) M. J. Waring, J. Mol. Biol., 1965, 13, 269 [Links]; (b) J.-B. LePecq and C. Paoletti, J. Mol. Biol., 1967, 27, 87 [Links].

45 M. Lee, A. L. Rhodes, M. D. Wyatt, S. Forrow and J. A. Hartley, Biochemistry, 1993, 32, 4237 [Links].

46 A. U. Khan, J. Phys. Chem., 1976, 80, 2219 [Links].

47 D. D. Perrin, W. L. F. Armarego and D. R. Perrin, Purification of Laboratory Chemicals, Pergamon Press, Oxford, 1980.

48 (a) J. E. Dickeson and L. A. Summers, Aust. J. Chem., 1970, 23, 102; (b) E. Amouyal, A. Homsi, J.-C. Chambron and J.-P. Sauvage, J. Chem. Soc., Dalton Trans., 1990, 1841 [Links].

49 O. Kahn, Molecular Magnetism, VCH, Weinheim, Germany, 1993.

50 N. Walker and D. Stuart, Acta Crystallogr., 1983, 39A, 158 [Links].

51 G. M. Sheldrick, SHELX-97, Program for crystal structure solution and refinement, University of Göttingen, Göttingen, Germany, 1997.

52 C. K. Johnson, ORTEP, III Report ORNL - 5138, Oak Ridge National Laboratory, Oak Ridge, TN, USA.

53 J. Marmur, J. Mol. Biol., 1961, 3, 208 [Links].

54 M. E. Reichmann, S. A. Rice, C. A. Thomas and P. Doty, J. Am. Chem. Soc., 1954, 76, 3047 [Links].

55 J. Bernadou, G. Pratviel, F. Bennis, M. Girardet and B. Meunier, Biochemistry, 1989, 28, 7268 [Links].

\section{Footnote}

† Electronic supplementary information (ESI) available: DNA binding plot, gel electrophoresis diagrams (Figs. S1-S4) and ORTEP diagram of 2 (Fig. S5). See http://www.rsc.org/suppdata/dt/b4/b416711b/

This journal is @ The Royal Society of Chemistry 2005 